\title{
THE EXISTENCE OF INDONESIAN LOCAL ART CULTURE THROUGH DIGITAL BASED COMMUNITY MEDIA
}

\author{
Rocky Prasetyo Jati \\ Universitas Budi Luhur, Indonesia. \\ rocky@budiluhur.ac.id
}

\begin{abstract}
The development of information and communication technology has brought a change in social life. That phenomenon also has an impact on the changes in the management strategies of the existing community media. The visible development of information and communication technology is also the development of the use of digital technology. Human innovation is currently focusing on electronic media which has been developed in the current digital age. The digital age is an era that leads humans to move from the use of analog technology in digital technology which is currently also rapidly growing with the convergence of Internet. During this period, conventional media or the traditional media acts as mass media delivered electronically. Local culture that has certain characteristics can be a product that has additional high value when it is adjusted to media development. Some efforts can be made to make community media as a mean to market local culture throughout the world. Those efforts can be made by incorporating local culture into the content of digital-based community media. Those efforts have been practiced by the Paguyuban Kridho Laras Karawitan and Paguyuban Karawitan Renggo Budoyo in Klaten. They used Internet technology with Facebook and YouTube as the platform.
\end{abstract}

Keywords: Existence, Art, Local Culture, Community Media, Digital Technology

\section{INTRODUCTION}

Globalization happens due to the advanced information and communication technology. Through information and communication technology, everything spread fast and widely not only in the developed countries but also in the developing countries. Meanwhile, the main part of the globalization process is in the developed countries. Those developed countries have made attempts to spread their local values to throughout the world. It is an easy thing to do for them because they master information and communication technology. This condition contradicts the condition in the developing countries that are only able to see and to accept the process of globalization. McLuhan in The Gutenberg Galaxy (1962: 36) explains the effect of media technology development which is the current human society lives within the scope of the global village. "We live in a single constructed space resonance with tribal drums." This metaphor used by McLuhan to explain the concept of the global village. That metaphor was based on technological discoveries which then create new sectors or fields to solve the overall problems faced by humans.

Rapid development in the era of globalization has given chance and convenience to global cultures (especially from developed countries) to enter every other country including Indonesia. Local culture is an indigenous culture that can be interpreted as a cultural characteristic of a group in interacting or behaving within the group. The concerned group can also be referred to as a community bound to a place or geographically. Local culture is the social identity of a society. At the moment, the younger generation is increasingly difficult to give meaning to the importance of cultural heritage, especially traditional arts that they have.

Culture is a national asset which can also be interpreted as a national identity. One of the problems faced by Indonesian society regarding the culture is the slow act of protecting cultural heritage. Thus, Indonesian culture and art are often claimed by other nations for several times. Moreover, in Indonesia, the inclusion of western values is a threat to its indigenous culture. Regional arts such as ludruk, ketoprak, wayang, gamelan, and various dances get serious threats from the development of typical western pop culture which is increasingly in demand by the public because it is considered more modern. The cultures which are considered conventional such as values of noble, tolerance, hospitality and respect for the elder are slowly lost because of promiscuity caused by globalization.

Globalization raises problems such as the lost of local cultural heritage. The changes in dress style, language style, and the use of information technology are the prove of low local cultural heritage. For example, the use of dress style which suits the other traditions can be considered fit to the global understanding. The use of national language is getting less and changed to the use of foreign language. Another example, nowadays, children are more familiar to the animation film characters of "Upin and Ipin" which represents the life of Malaysian compared to the characters of Unyil which represents Indonesian society. Those are the simple proves that technology such as the Internet, satellite dish, and television makes it possible for people from the other side of 
the world to get fast access to information from the other. The objective of this study was to review the results of observations and research which had been carried out on the local cultural community media. Community media are communities of practice which can be defined as a group of people who have the same concern and do something regularly. This study attempted to explain how community media efforts maintain the existence of local cultural arts in the middle of the globalization era by formulating several strategies and steps to strengthen and maintain national identity.

\section{PRELIMINARY STUDY ON THE COMMUNITY MEDIA IN INDONESIA}

This study could not be separated from several previous studies. A study entitled "Penggunaan Media Komunikasi dalam Eksistensi Budaya Lokal bagi Komunitas Tanah Aksara" (The Use of Communication as Media in the Existence of Local Culture for Tanah Aksara Community) conducted by Nuryah Asri Sjafirah and Ditha Prasanti was conducted in the modern era. In that study, it was stated that "Culture has increasingly developed into a popular culture because of the influence of western culture. Apparently, there is still a community that wants to maintain the tradition of local cultural heritage in the field of literature". The researchers conducted an in-depth study on the use of communication media in the existence of culture in Tanah Aksara community located in Bandung. The existence of 'sense of belonging' culture was one of the characteristics of Tanah Aksara community. In that study, the use of communication media in the existence of Tanah Aksara community was including the use of social media such as Facebook, Instagram, and Twitter of Tanah Aksara community. These communication media were considered as effective to show the existence of local culture owned by Tanah Aksara community.

Another study was conducted by Combine Resource Institution. The book entitled "Pergulatan Media Komunitas di Tengah Arus Media Baru" (The Struggle of Community Media in the Midst of New Media) was a result of the study conducted by Mario Antonius Birowo, Idha Saraswati, Ranggabumi Nuswantoro and Ferdhi Fachrudin Putra. That study examined the efforts of community media in dealing with the development of new media technology. Inside the book, there was a matter of how the activists adapt to the development of new media either from the production process or the management of their institutions. The methodology used was a case study on the five community media in Indonesia which were Best FM Community Radio, Wijaya FM Community Radio, Suandri FM Community Radio, Primadona FM Community Radio, and Speaker Kampung Community Media. The result of that study was that there was a new challenged faced by community media in the utilization of the latest information and communication technology which was related to new media.

In Indonesia, the most developed community media are community media with radio channels. Radio becomes the chosen media used by many communities. The result of the preliminary study showed that radio was considered as the easiest media in managing its production and its technical implementation. Many studies had been conducted on community radio in Indonesia. Related studies on how the radio broadcast program has implications for the formation of identity and the expression of culture had been conducted by Suryadi (2005) entitled "Identity, Media, and the Margins: Radio in Pekanbaru, Riau" and Sujoko (2011) entitled "Talking Culture: Indonesian Community Radio and the Active Audience". A study on community radio and its relation to the changes in society also had been conducted by Eni Maryani (2011) entitled "Media and Social Changes: Voice of Resistance through Community Radio".

From the previous studies, it can be inferred that initially community media used in Indonesia was only radio. However, there was a change. The community started to follow the change of information and communication technology. In order to maintain the strength of community, a community has to use multi-platform media.

\section{DIGITAL BASED COMMUNITY MEDIA}

Referring to Howley's statement in 2005 in "Community Media: People Places and Communication Technologies", discussion regarding community media focused on the lack of concern from political economic thinkers on the participatory media which is oriented to the micro interest such as community. According to Howley, the analysis on a local situation such as community media could explain the process of message and influence exchange (not equal to) between community media and mainstream media as well as corporate media which is transnational. Howley's (2005) approach gave new insight on community media. The existence of community media is not only considered as communication media which leads to the society but it is also considered as a structure which forms a community. Dialectic structure of community media and community life is seen later by paying attention to community life. The choice of types of media published in the form of print, radio, television, and portals was preceded by a dialectical process that forms a decision why a type of media are chosen at last.

The development of information and communication technology has brought a change in social life. That phenomenon also has an impact on the changes in the management strategies of the existing community media. 
The visible development of information and communication technology is also the development of the use of digital technology. Human innovation is currently focusing on electronic media which has been developed in the current digital age. The digital age is an era that leads humans to move from the use of analog technology in digital technology which is currently also rapidly growing with the convergence of Internet. During this period, conventional media or the traditional media acts as mass media delivered electronically.

Human habits as audiences also change with the emergence of innovations made through private media. For example, nowadays, people are able to download or to do live streaming on music independently with the help of technology. This encourages people to change in how they enjoy the music. People switch their broadcast radio from the analog device into website or mobile application on smartphones to enjoy music. Certainly, this change brings an effect on the music industry because previously it focused on selling music through the CD. Nowadays, it may be rare to find a household that still has a dual-band transistor radio and still subscribes to a daily newspaper. Otherwise, it can be ascertained that in every household there is the presence of television equipped with supporting devices with an Internet connection such as a smartphone or Internet modem (Modulator-Demodulator). Another change is that people are no longer become the consumer. They make attempt to be producer by producing contents spread widely through digital based media. Podcast, a mean for vlog (video blog), can be one of the examples of that innovation.

Human becomes a multitasked that is able to do many activities at the same time in a certain time. In a day, human is able to do various activities and, at the same time, human is able to consume other media such as enewspaper, music stream service or radio. The need of multitasking or multifunction device is fulfilled by the development of media convergence. Media convergence is technology which is able to meet the challenge of human's need.

There are many elements of the society such as groups, organizations, or communities who use communicational media in form of media convergence. Community media such as mainstream media or conventional media also use media convergence strategy to maintain and to keep its existence. With the help of media convergence, community media are currently able to emerge with various types of media. Community media which was originally only developed in the form of community radio, community television, or community magazines, through Internet technology; it can be developed into convergent media which is often referred to as new media.

Community media as an alternative media according to Downing (2003) is the form of people resistance to the mainstream media. Alternative media does not measure its success through the number of people or income but through its ability in starting communication in an alternative space existed at community level or through the existed social network.

Internet technology is an important part of the existence of the community media. Originally, Internet is considered as an alternative media that helped in solving the main problems faced by the community media which are the limitations of broadcasting. However, the existence of Internet currently becomes a common thing. Its role as "alternative media" changes into something different. Alternative media and Internet are faced with the dependence on the conditions of society, social, political, and economic. Meanwhile, technological progress is part of human existence in the world. According to internetworldstas.com, Indonesia had 143 million Internet users in December 2017, with the penetration percentage of 53.7\%. Aside from being seen through the number of Internet users, the increasing use of digital media can also be seen from the number of online activities. Social network such as Twitter and Facebook is the most commonly used media.

\section{ALTERNATIVE MEDIA FOR LOCAL CULTURAL ART}

The threat of the extinction of traditional culture will not occur if in every region there is a community or a group that has the desire to jointly maintain the culture. For example, in Gantiwarno Klaten, there are two local cultural arts communities of "karawitan". Those two communities are Paguyuban Karawitan Kridho Laras and Paguyuban Karawitan Renggo Budoyo. Those two communities make use of Internet as their community media. They regularly use YouTube through Internet to broadcast their acts in live streaming. They also present their local cultural arts stage activities using a media channel called Galuh Prambanan TV. That channel was named after the location of the pavilion used for the regular activities of the community.

Community media can be categorized based on geographical factors or based on community's interest. Community media can be started from certain ethnicities, gender, sexual orientation, political relation, lifestyle, or the taste of art and music. Various types of community media existed in Indonesia reflect the heterogeneity and the needs of Indonesian community for knowledge, information, and entertainment. Chris Atton (2002: 9) mentioned community media as part of alternative media. Community media also deals with the development of communication as its participatory form. Sadly, community media also has a label as a 'radical' media because it is also used by oppressed or marginalized groups. 


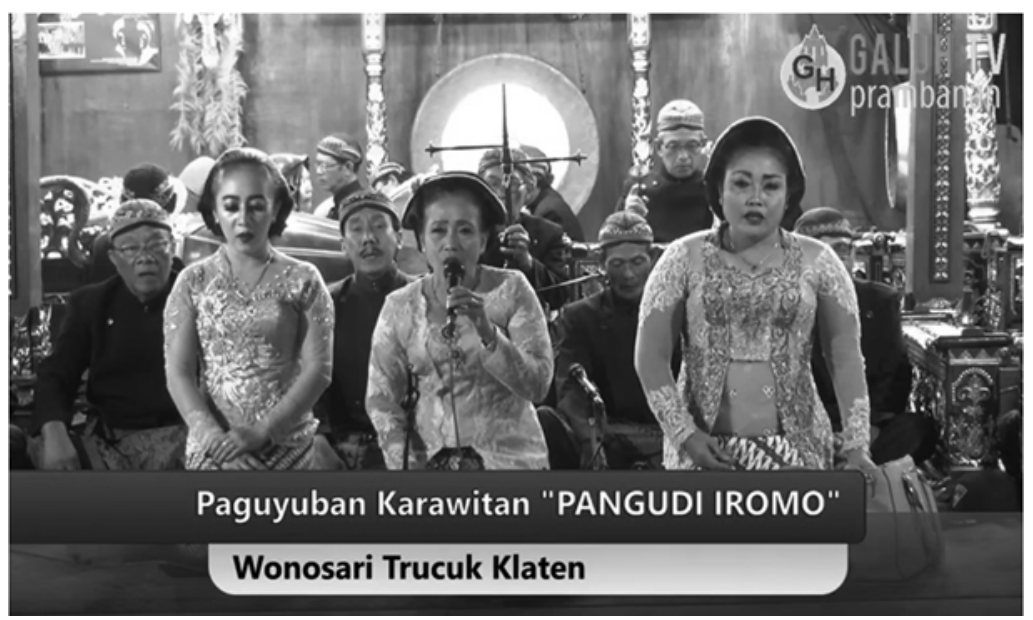

Picture 1. Galuh Prambanan TV Audio Visual Display (Source: http://galuhprambanan.tv)

The local cultural arts community is a system that exists in the social system of society. The same goes for the wider social system, the system in the community contains the structure and function even though sometimes they have different goals. The art community has specific goals while the social system of society certainly has broader and more complex goals and function.

Paguyuban Karawitan Kridho Laras and Paguyuban Karawitan Renggo Budoyo are communities that carry the spirit of preserving traditional musical arts such as karawitan. Those two communities show their existence in preserving traditional art namely karawitan. The members of those communities were young to old artists who have concern for traditional arts. These communities expect to always preserve, promote, and pass on the traditional arts to the younger generation. Therefore, an art approach has emerged. That approach is carried out by using traditional media which is collaborated with modern media especially in the broadcasting pattern. This is one of the strategies done in order to keep the art to not too outdated or to make it able to adapt to the modern media.

The local cultural arts community uses modern media such as Internet by using applications such as YouTube, Facebook, or other social media in broadcasting their art performances. Those media are one of the efforts made by the community to show their social identity to the wider community or throughout the world. This act is commonly called as globalization of local content.

Nowadays, the rapid growth of social media greatly influences the development of mainstream and community media. The community media referred to in this study covers various media such as press, photography, film, graphic, arts, theater, radio, and video. However, some subtopics in this article describe more about the existence of radio-type media. Community media has some basic characteristics. One of the basic characteristics is that community media are not run to get financial benefit but to aim for social benefit and community benefit. Community media are owned by and are responsible to the communities they serve. Community media present society participation in produce and manage community.

\section{CONCLUSION}

Refusing the existence of globalization cannot solve the problem faced regarding the decrease of public attention to cultural arts and the preservation of cultural heritage. Inhibiting the pace of globalization is the same as inhibiting the advances in technology and science. Thus, a strategy is needed to face the concerned problem. Community media can be one of the strategies to maintain cultural arts because community media are produced by communities who understand the community better compared to the other mainstream media. Utilizing information and communication technology is also an effort to preserve and develop local cultural values. Moreover, the utilization of information and communication technology is able to introduce local cultural values to the global level through locality globally.

Local culture that has certain characteristics can be a product that has additional high value when it is adjusted to media development. Some efforts can be made to make community media as a mean to market local culture throughout the world. Those efforts can be made by incorporating local culture into the content of digital-based community media. Those efforts have been practiced by the Paguyuban Kridho Laras Karawitan and Paguyuban Karawitan Renggo Budoyo in Klaten. They used Internet technology with YouTube as the platform. The attractiveness of local culture will be even more attractive by perfectly using YouTube features. Its attractiveness 
then will lead to increase economic and investment attractiveness. Internet optimization can also make local cultural arts capable of having a broader or global role. Community media is developing not only through the use of radio technology but also through the utilization of other digital media such as YouTube, websites, and live streaming technology. Then, technology manages to grow from the local culture to be used as a means of anticipation in order to develop culture and future conditions. Nowadays, people in the digital era di era certainly always try to develop innovation so that traditional arts can become part of modern life. Traditional arts can be consumed or enjoyed by modern society by making various modifications of the art forms used by the commodity.

\section{REFERENCES}

Atton, Chris. (2002). Alternative Media. London: Sage Publications.

Birowo, M.A. (2006). “Community Radio Movement in Indonesia: a case study of Jaringan Radio Komunitas Yogyakarta”. Atma Jaya Yogyakarta University/Media Asia Research Group-Curtin University of Technology.

Flew, T. (2008). New Media: An Introduction. Melbourne: Oxford University Press.

Howley, K. (2005). Community Media: People Places, and Communication Technologies. Cambridge: Cambridge University Press.

Maryani, E. (2011). Media dan Perubahan Sosial: Suara Perlawanan Radio Komunitas. Bandung: Rosdakarya. McLuhan, Marshall. (1962). The Gutenberg Galaxy. Toronto \& New York: University of Toronto Press.

Mosco, V. (2009). The Political Economy of Communication: $2^{\text {nd }}$ Edition. London: Sage Pubs.

Orlikowski, W.J. (2000). "Using Technology and Constituting Structures: A Practice Lens for Studying Technology in Organizations”. Organization Science. Vol. 11 (4), 404-428.

Sujoko, A. (2011). "Talking Culture: Indonesian Community Radio and the Active Audience". Social Alternatives. Vol 30, pp. 16.

Suryadi (2005). "Identity, Media, and the Margins: Radio in Pekanbaru, Riau". Journal of Southeast Asian Studies. Vol 36, No.1, pp. 131-151. 